\title{
INFLUENCE OF SOLUTION PRECURSORS ON STRUCTURE OF ZnO FILMS
}

\author{
T.O. Berestok, A.S. Opanasyuk \\ ${ }^{1}$ Sumy State University, Rimsky-Korsakov Str., 2, 40007, Sumy, Ukraine \\ taisia.berestok@ukr.net
}

Owing to the wide range of zinc oxide applications as the base material of creation of gas sensors, sensors of various types of radiation, devices of micro- and optoelectronics, it has attracted a great attention of researchers. Due to a large band gap $E_{g}=3.37 \mathrm{eV}, \mathrm{ZnO}$ can be used as window and conductive layers of solar cells.

Using synthesis of $\mathrm{ZnO}$ by low-temperature and non-vacuum methods, there is the possibility of obtaining condensates onto flexible substrates with controlled structural characteristics: nanodots, nanofibers, nano-porous and continuous condensates, depending on the deposition conditions and initial precursors. Therefore in the work we performed the determining of the relationship between the physical and technological conditions of the deposition, the composition of the initial solution and structural properties of the synthesized $\mathrm{ZnO}$ samples.

The synthesis of two series of samples of zinc oxide condensates was performed by the method of chemical bath deposition at reactor temperature of $90{ }^{\circ} \mathrm{C}$. To compare the structural characteristics of the obtained films as a starting precursors we selected solutions of zinc acetate and zinc nitrate. To maintain the $\mathrm{pH}$ at 10 there was added a solution of ammonia to the initial mixture. As a substrate we used glass and glass with underlayer of FTO. Investigation of the morphology of the synthesized samples was performed using a scanning electron microscope ZEISS Avirguda. Structural studies were carried out by an automated diffractometer Bruker D8 Advance in Ni-filtered of $K_{\alpha}$ radiation of copper anode.

Studies have shown that using the chemical bath deposition from zinc nitrate solution, zinc oxide condensates have poor adhesion to the surface of the glass substrate; and films' growth occurred through the formation of an ordered array of nanorods. When the deposition of condensation was performed on the substrate with FTO underlayer from zinc acetate solution, there was the formation of $\mathrm{ZnO}$ nanoflowers with a high specific surface area. Thus deposited layers have high adhesion to the surface of the substrate.

The results have shown that the samples were single phase and had a hexagonal structure. It was established that $\mathrm{ZnO}$ samples deposited from a solution of zinc nitrate have $(f$ $=0.45-1.83$ ) high texture growth of [002]; while the samples, that were grown using zinc acetate as a source precursor, had the worst texture growth $(f=0.16-0.27)$, quality of which depends on the duration of the deposition. Precision values of lattice parameters of the material ( $a=0.32486 \mathrm{~nm}, c=0.52087 \mathrm{~nm}$ - for condensates deposited from a solution of zinc nitrate; $a=0.32514 \mathrm{~nm}, c=0.5208 \mathrm{~nm}$ - deposited from a solution of zinc acetate) showed that these values are well correlate with reference one $(a=0.3256 \mathrm{~nm}, c=0.5212 \mathrm{~nm})$.

With the help of these researches we can choose the optimal conditions to obtain $\mathrm{ZnO}$ films with controlled structural properties that can be used as a base layers in microelectronics devices. 
Influence of solution precursors on structure of $\mathrm{ZnO}$ films / Berestok T.O., Opanasyuk A.S,// 6-та Міжнародна науково-технічна конференція "Сенсорна електроніка та мікросистемні технології" (з виставкою розробок та промислових зразків сенсорів) "СЕМСТ-6", Україна, Одеса, 29.09 - 03.10.2014 р. С. 56 